\title{
ARTICLE
}

\section{Comparative anatomical and micromorphological study of some Rumex species (Polygonaceae)}

\author{
Maryam Keshavarzi*, Farzaneh Ebrahimi, Samaneh Mosaferi \\ Department of Plant Science, Faculty of Biological Sciences, Alzahra University, Tehran, Iran
}

\begin{abstract}
Rumex (Polygonaceae) is a large genus of annual, biennial and perennial species in temperate regions of the world. In Iran it is represented by 23 species and some hybrids classified in three subgenera. The species identification is difficult due to the importance of fruit features in species separation despite the fact, that plants lose their flower and some other features while bearing fruits. Providing the individuals with the proper set of diagnostic features is very difficult. There are inadequate anatomical studies of Rumex. The present study reports the first detailed stem anatomy and epidermis micromorphology of 6 species of Rumex in Iran. Main aims of this study were to find the diagnostic value of the adopted features. Cross sections were made by hand and double colored. Dorsal and ventral leaf epidermises were studied by Scanning Electron Microscopy (SEM). Results of stem anatomical study showed that collateral vascular bundle is only present in $R$. chalepensis and oxalate calcium druse crystals were only absent in $R$. elbrusensis. The micro-morphological study of epidermis showed that all species studied had anisocytic stomata type, but there were differences in the epidermis and stomata cell size. Species relationships based on the results have been discussed. Acta Biol Szeged 62(1):45-52 (2018)
\end{abstract}

\author{
KEY WORDS \\ Iran \\ leaf epidermis \\ Polygonaceae \\ Rumex \\ stem anatomy
ARTICLE INFORMATION
Submitted
17 November 2017
Accepted
4 March 2018.
*Corresponding author
E-mail: m.keshavarzi@alzahra.ac.ir \\ neshat112000@yahoo.com
}

\section{Introduction}

Polygonaceae is a complex family with 59 genera and nearly 1200 species in the world (The Plant List 2013). Rumex L. is a large genus with 200 species, which are distributed in different habitats of temperate regions of the world (Sanchez and Kron 2008; Chase and Reveal 2009). In Iran it is represented by 23 species and some hybrids classified in three subgenera as subgenus Acetosella, subgenus Acetosa and subgenus Rumex from which the latter is the largest with more species (Rechinger 1968; Mozaffarian 1988).

These are annual, biennial and perennial herbs or rarely suffrutices with basal and cauline leaves. Flowers are hermaphrodite, polygamous or unisexual with 6-segments perianth and 6 stamens arranged in panicle, cyme or axile inflorescences (Rechinger 1968). Rumex species are distributed in different habitats of Iran and are of medicinal importance in folk medicine (Mozaffarian 2015).

The species identification is somehow difficult due to the importance of fruit features in species separation. From the other hand, the plants loss their flower and some other features while bearing fruits so finding individuals with the proper set of diagnostic features is difficult
(Rechinger 1968). Anatomical studies in Polygonaceae are mainly focused on leaf anatomy. Leaf anatomical observation provided some diagnostic features in Polygonum, Rumex, Persicaria, Fagopyrum, Pteropyrum and Rheum (Lersten and Curtis 1992; Hameed et al. 2010; Yasmin et al. 2010 a, b; Keshavarzi et al. 2012; Soleimani et al. 2014). Stem anatomy of some Polygonum species illustrated that anatomical features can be valuable in species delimitation especially about similar taxa (Nazem Bokaee et al. 2015). Micromorphology of epidermis in Polygonaceae has been studied by different authors. Ronse Decraene and Akeroyd (1988) illustrated the diagnostic value of epidermis. Hong et al. (1998) focused on the tepal micromorphology and found main differences in Polygonaceae. Yasmin et al. (2010 a) studied the leaf epidermis of selected Persicaria species. Tahey found variations in size and shape of epidermal cells, stomata, glandular and non-glandular trichomes. They used micro-morphological features of epidermis to elucidate relationship among different taxa.

There are inadequate literatures about the internal structure of Rumex (Joschi 1936; Li et al. 2008; Hameed et al. 2010; Sahney and Vibhasa 2012). The present study reports the first detailed stem and epidermis anatomy of six Rumex species as: $R$. chalepensis Mill., $R$. dentatus L., $R$. elbrusensis Boiss., $R$. conglomerates Murray, R. pulcher 
L., and $R$. vesicarius L. Main aims of this study were to illustrate the stem and epidermis anatomical features of the studied species and to discuss diagnostic value of the adopted features.

\section{Materials and Methods}

Six different Rumex species were studied from the viewpoint of their stem anatomy and epidermis structure (Table 1). Materials were gathered from nature during 2015-2017 in summer and autumn. All studied vouchers are deposited in Herbarium of Alzahra University (ALUH). For each specimen, proper replications were used. Anatomical structures of stem were studied by 4 quantitative features and 8 qualitative ones (Table 2). Anatomical structures were studied in manually sliced

Table 1. Voucher details of Rumex species studied (asterisk marks perennial species).

\begin{tabular}{|c|c|c|}
\hline Subgenus & Species & Locality \\
\hline \multirow[t]{20}{*}{ Rumex } & \multirow[t]{10}{*}{ R. chalepensis * } & $\begin{array}{l}\text { Alborz, Karaj, } \\
1202 \text { ALUH }\end{array}$ \\
\hline & & $\begin{array}{l}\text { Guilan, Bandare- Anzali, } \\
1201 \text { ALUH }\end{array}$ \\
\hline & & $\begin{array}{l}\text { Khorasan Razavi, Torbat-e Heydarieh, } \\
1206 \text { ALUH }\end{array}$ \\
\hline & & $\begin{array}{l}\text { Khorasan Razavi, Quchan, } \\
1203 \text { ALUH }\end{array}$ \\
\hline & & $\begin{array}{l}\text { Khuzestan, Masjed Soleyman, } \\
1209 \text { ALUH }\end{array}$ \\
\hline & & $\begin{array}{l}\text { Mazandaran, Amol, } \\
1205 \text { ALUH }\end{array}$ \\
\hline & & $\begin{array}{l}\text { Mazandaran, Sari, } \\
1602 \text { ALUH }\end{array}$ \\
\hline & & $\begin{array}{l}\text { Qom, } 20 \text { km of Qom-Kashan, Pasangan, } \\
1207 \text { ALUH }\end{array}$ \\
\hline & & $\begin{array}{l}\text { Tehran, Abali, } \\
1245 \text { ALUH }\end{array}$ \\
\hline & & $\begin{array}{l}\text { Tehran, Darakeh, } \\
1208 \text { ALUH }\end{array}$ \\
\hline & \multirow[t]{4}{*}{ R. conglomeratus* } & $\begin{array}{l}\text { Guilan, Bandar-e Anzali, } \\
1211 \text { ALUH }\end{array}$ \\
\hline & & $\begin{array}{l}\text { Guilan, Rudsar, } \\
1212 \text { ALUH }\end{array}$ \\
\hline & & $\begin{array}{l}\text { Guilan, Sowme'eh Sara, } \\
122 \mathrm{ALUH}\end{array}$ \\
\hline & & $\begin{array}{l}\text { Mazandaran, Amol, } \\
1217 \text { ALUH }\end{array}$ \\
\hline & \multirow[t]{2}{*}{ R. dentatus } & $\begin{array}{l}\text { Tehran, Vanak, } \\
1502 \text { ALUH }\end{array}$ \\
\hline & & $\begin{array}{l}\text { Khuzestan, Behbahan, } \\
1214 \text { ALUH }\end{array}$ \\
\hline & \multirow[t]{2}{*}{ R. elbrusensis* } & $\begin{array}{l}\text { Alborz, Mardabad, } \\
1246 \text { ALUH }\end{array}$ \\
\hline & & $\begin{array}{l}\text { Guilan, Rasht, } \\
1223 \text { ALUH }\end{array}$ \\
\hline & \multirow[t]{2}{*}{ R. pulcher* } & $\begin{array}{l}\text { Alborz, Malard, } \\
2255 \text { ALUH }\end{array}$ \\
\hline & & $\begin{array}{l}\text { Tehran, Taleghani Park, } \\
1229 \text { ALUH }\end{array}$ \\
\hline \multirow[t]{2}{*}{ Acetosella } & \multirow[t]{2}{*}{ R. vesicarius } & $\begin{array}{l}\text { South Khorasan, Ozbagu, } \\
5241 \text { ALUH }\end{array}$ \\
\hline & & $\begin{array}{l}\text { Fars, Kazerun, } \\
1200 \text { ALUH }\end{array}$ \\
\hline
\end{tabular}
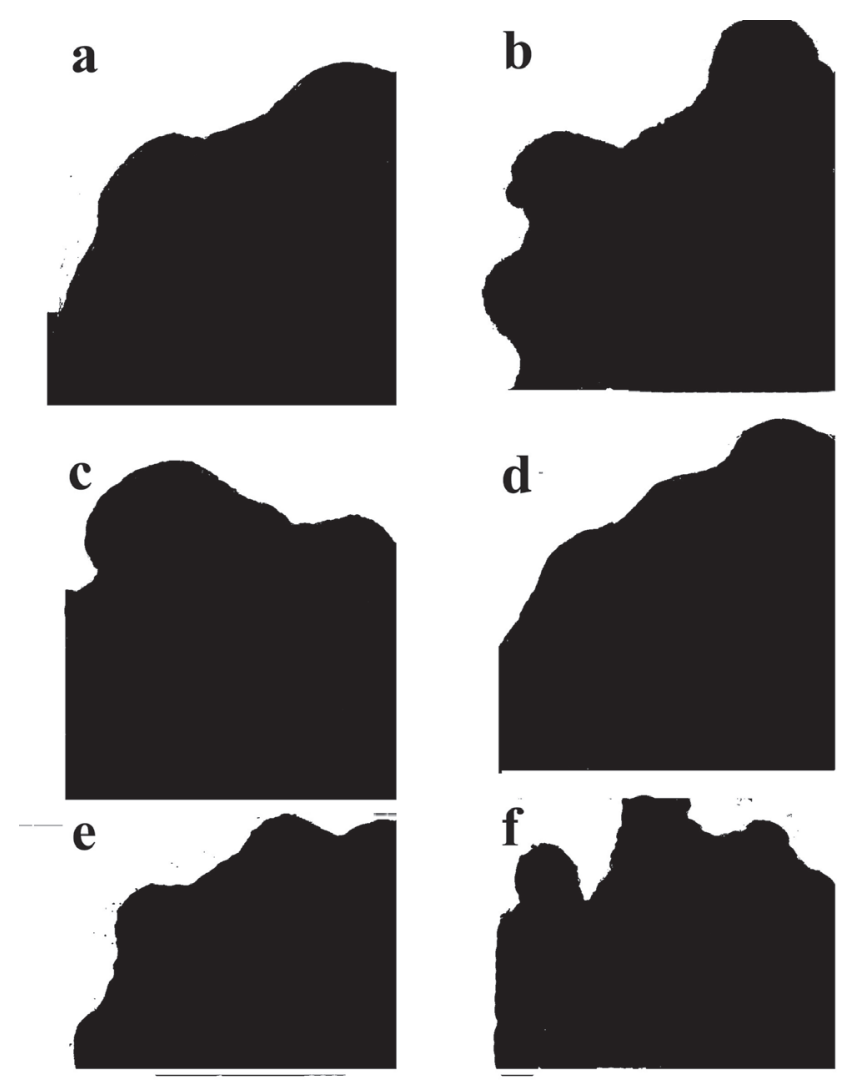

Figure 1. General shape of stem cross section in Rumex species studied. a) $R$. chalepensis; b) $R$. conglomeratus; c) $R$. dentatus; d) $R$. elbrusensis; e) $R$. pulcher; f) $R$. vesicarius.

cross sections, after double staining with methyl green and Congo red. Cross sections were subsequently observed with an Olympus DP 12 light microscope.

The dorsal and ventral leaf epidermis of all the studied six species were examined by SEM. For SEM studies leaf surface were mounted on stub using double sided cello tape and coated with gold in a sputtering chamber (Sputter Coater BAL-TEC, SCDOOS). Epidermis do not encounter with any pretreatment. Coating with gold by the physical vapor deposition method (PVD) was restricted to $100 \AA$. The SEM examination was carried out on a TESCAN microscope. The measurements were based on 10-20 readings for each specimen. The terminology of Punt et al. (2007) for leaf micromorphology and Metcalfe and Chalk (1950) for stem anatomy was followed.

In order, to detect significant differences in the studied characters among studied species, Analysis of Variance (ANOVA) was performed. To reveal the species relationships, cluster analysis and principal component analysis (PCA) were used. For multivariate analysis, the mean quantitative characters were applied, while qualitative characters were coded as binary/multi-state characters. Standardized variables were used for a multivariate sta- 


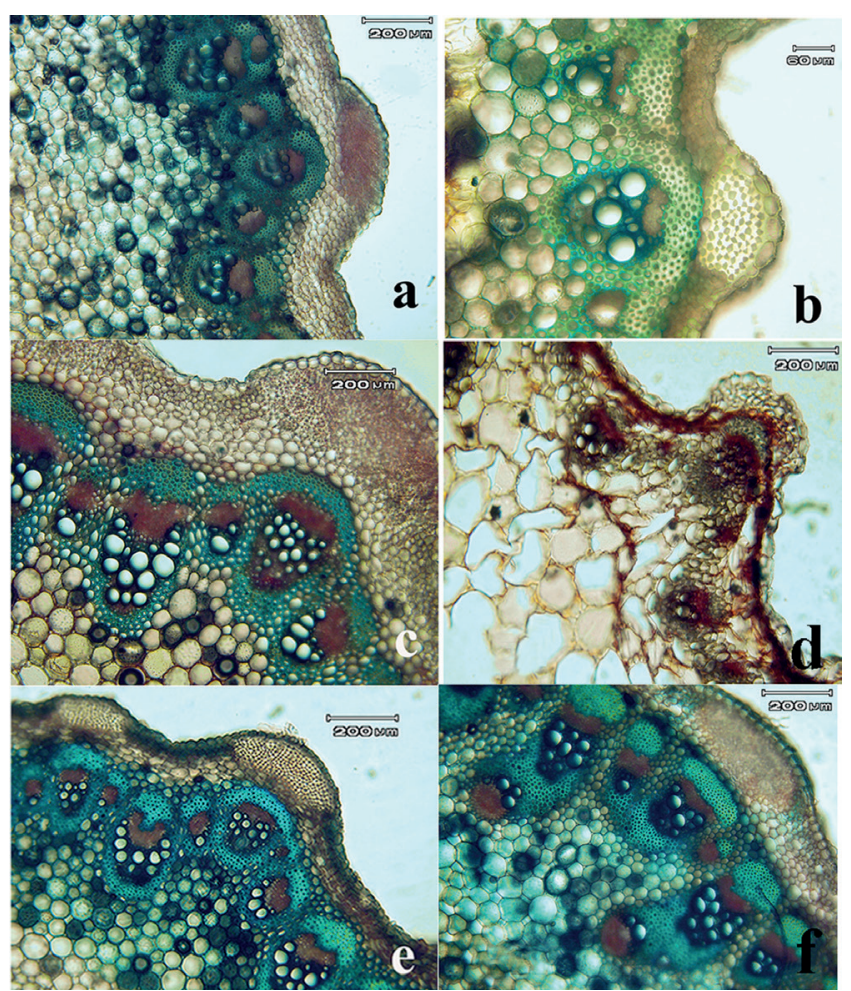

Figure 2. Stem cross section in Rumex species studied. a) $R$. chalepensis; b) $R$. conglomeratus; c) $R$. dentatus; d) $R$. vesicarius; e) $R$. pulcher; f) $R$. elbrusensis.

tistical analysis. The average taxonomic distances and squared Euclidean distances were applied as dissimilarity coefficient in the cluster analysis of anatomical data. In order, to determine the most variable anatomical characters among the studied species, a factor analysis based on the principal components analysis was performed. The PAST ver. $2.17 \mathrm{c}$ software was used for statistical analyses.

\section{Results}

\section{Stem anatomical features}

The shape of the cross-section is polygonal-protuberant, with different degree of prominence protuberances (Fig. 1). The epidermis presents cells, with the external wall thicker than the others. Epidermis is covered by a cuticle. A cord of sclerenchymatous fibers is present in the protuberances, under the stem epidermis. The central cylinder has vascular tissues arranged in one ring. Cords of sclerenchymatous fibers are visible at the periphery of each vascular bundle. The medulla is made of spongy parenchyma.

In $R$. chalepensis, ribs are short dome and regularly arranged. Parenchyma is composed of almost 8 layers and vascular bundles are in form of collateral bundles.
The sclerenchymatous cap on phloem is arch-shaped (Fig. 2a). In $R$. conglomerates ribs are shaped as large domes with deep groves which are arranged regularly. There are five parenchyma layers and vascular bundles are in form of bicollateral bundles (Fig. 2b). Ribs shapes in $R$. dentatus are in different sized dome, but in $R$. vesicarius, it is in form of deeply groves small ribs (Fig. 2c). Ribs are arranged in $R$. dentatus irregularly but in $R$. vesicarius they are regular. The number of parenchyma layers is less in $R$. vesicarius than $R$. dentatus. Both showed bicollateral vascular bundles and arch-shaped sclerenchymatous cap on phloem (Fig. 2d).

Ribs in R. pulcher are in form of large domes which are irregularly arranged. There are 7 parenchyma layers as cortex and oxalate calcium druses crystals are present (Fig. 2e). Vascular bundles are bicollateral and the arch of sclerenchymatous cap on phloem is observed. In $R$. elbrusensis the complete sclerenchymatous sheath was not present. Only on this species medullary vascular bundle was observed. Rib shapes are in form of very short dome with regular arrangement (Fig. 2f). On the outer stem surface trichomes are observed. Cortex parenchyma is composed of 9 layers. In R. elbrusensis no oxalate calcium druse crystal was observed. This species has bicollateral vascular bundles. The other difference is the shape of sclerenchymatous cap of phloem, which is not archshaped and is in form of horizontal mass. Moreover, internal bundles can be seen in this taxon. There are also quantitative differences which are mentioned in Table 2.

\section{Leaf epidermis micromorphology}

The epidermis is made of polygonal cells with straight lateral walls; stomata, often anisocytic, are visible in both epidermis. Numerous druses of calcium oxalate are visible through the transparency. A comparison of
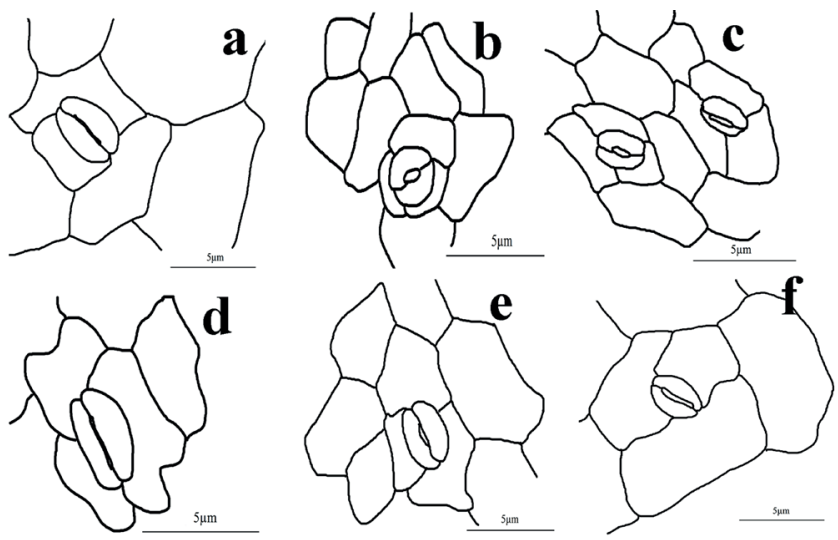

Figure 3. Leaf dorsal epidermis in Rumex species studied. a) $R$. chalepensis; b) $R$. conglomerates; c) $R$. dentatus; d) $R$. elbrusensis; e) $R$. pulcher; f) $R$. vesicarius. Scale bar is $5 \mu \mathrm{m}$. 
Table 2. Results of stem cross section features in Rumex species studied.

\begin{tabular}{|c|c|c|c|c|c|c|}
\hline \multirow{2}{*}{ Character } & \multicolumn{6}{|c|}{ Taxon } \\
\hline & R. chalepensis & R. conglomeratus & R. dentatus & R. elbrusensis & R. pulcher & R. vesicarius \\
\hline Complete sclerenchyma sheath & present & absent & absent & absent & present & absent \\
\hline Medullary vascular bundles & absent & absent & absent & present & absent & absent \\
\hline Rib shape & short dome & $\begin{array}{l}\text { large dome with } \\
\text { deep groves }\end{array}$ & $\begin{array}{l}\text { different sized } \\
\text { dome }\end{array}$ & $\begin{array}{l}\text { very short } \\
\text { dome }\end{array}$ & large dome & $\begin{array}{l}\text { deeply grooved } \\
\text { small }\end{array}$ \\
\hline Rib arrangement & regular & regular & irregular & regular & irregular & regular \\
\hline Trichome on outer stem surface & absent & absent & present & present & absent & present \\
\hline Parenchyma layers & 8 & 5 & 7 & 9 & 7 & 3 \\
\hline Oxalate calcium druse crystals & present & present & present & absent & present & present \\
\hline Vascular bundle & collateral & bicollateral & bicollateral & bicollateral & bicollateral & bicollateral \\
\hline $\begin{array}{l}\text { Shape of sclerenchyma cap of } \\
\text { phloem }\end{array}$ & arch & arch & arch & horizontal mass & arch & arch \\
\hline Average epidermis thickness & $25.55 \mu \mathrm{m}$ & $14.60 \mu \mathrm{m}$ & $24.41 \mu \mathrm{m}$ & $18.97 \mu \mathrm{m}$ & $17.12 \mu \mathrm{m}$ & $21.14 \mu \mathrm{m}$ \\
\hline Average vascular bundles diameter & $93.70 \mu \mathrm{m}$ & $105.88 \mu \mathrm{m}$ & $107.50 \mu \mathrm{m}$ & $91.01 \mu \mathrm{m}$ & $95.33 \mu \mathrm{m}$ & $79.34 \mu \mathrm{m}$ \\
\hline $\begin{array}{l}\text { Average thickness of sclerenchyma } \\
\text { fibers over phloem }\end{array}$ & $43.11 \mu \mathrm{m}$ & $61.78 \mu \mathrm{m}$ & $63.24 \mu \mathrm{m}$ & $66.59 \mu \mathrm{m}$ & $50.31 \mu \mathrm{m}$ & $33.48 \mu \mathrm{m}$ \\
\hline
\end{tabular}

Table 3. Comparative epidermis features in Rumex species studied.

\begin{tabular}{|c|c|c|c|c|c|c|c|}
\hline \multirow{2}{*}{ Species } & \multicolumn{2}{|c|}{ Stomata type } & \multicolumn{2}{|c|}{$\begin{array}{c}\text { Cell size } \\
\text { Adaxial }(\mu \mathrm{m})\end{array}$} & \multicolumn{2}{|c|}{$\begin{array}{c}\text { Cell size } \\
\text { Abaxial }(\mu \mathrm{m})\end{array}$} & \multirow[t]{2}{*}{$\begin{array}{c}\text { Stomata } \\
\text { average size }(\mu \mathrm{m})\end{array}$} \\
\hline & Ventral & Dorsal & Min & Max & Min & Max & \\
\hline R. chalepensis & anisocytic & anisocytic & 3.8 & 7.6 & 3 & 6.5 & 4.06 \\
\hline R. conglomeratus & anisocytic & anisocytic & 2.28 & 3.0 & 2.18 & 6 & 1.995 \\
\hline R. dentatus & anisocytic & anisocytic & 2.21 & 3.61 & 2.78 & 5.99 & 2.179 \\
\hline R. elbrusensis & anisoparacytic & anisocytic & 4.57 & 4.9 & 3.41 & 5.96 & 3.778 \\
\hline R. pulcher & anisocytic & anisocytic & 3.35 & 3.61 & 2.801 & 7.4 & 2.98 \\
\hline R. vesicarius & anisocytic & anisocytic & 4.03 & 8.84 & 3.06 & 4.907 & 3.17 \\
\hline
\end{tabular}

epidermis features in species studied in Table 3. Ventral leaf epidermis of all species showed anisocytic stomata type, although, the size of three surrounding cells and their angles are somehow varied in different species (Fig. 3). In R. elbrusensis stomata type is similar, to paracytic type in leaf ventral surface. The size of epidermal cells varies from 2.21 to $8.84 \mu \mathrm{m}$ on adaxial surface and from 2.17 to $7.4 \mu \mathrm{m}$ on abaxial surface. $R$. conglomeratus had the finest and smallest ventral epidermal cells while $R$. vesicarus has the largest one. In dorsal epidermis, $R$. conglomeratus showed the smallest cells and R. pulcher had the largest one. Largest stomata were observed in $R$. chalepensis while the smallest were in R. conglomeratus (Fig. 3).

Studying the SEM micrograph of dorsal and ventral leaf epidermis showed some details of the epicuticular wax and epidermis features. $R$. chalepensis has wrinkled cuticle on both surface epidermis. Wax is in form of smooth layers and granules. In some parts of ventral surface, a kind of striate ornamentation is observed (Fig. 4). R. conglomeratus showed a dorsal leaf epidermis which is composed of

Table 4. ANOVA results of quantitative anatomical and epidermal characters in Rumex species studied.

\begin{tabular}{lllllll}
\hline Source of variation & SS & Df & MS & F & P-value & F crit \\
\hline Between groups & 41695.88 & 5 & 8339.175 & 167.3471 & $5.75 \mathrm{E}-21$ & 2.533555 \\
Within groups & 1494.949 & 30 & 49.83162 & & \\
Total & 43190.83 & 35 & & & \\
\hline
\end{tabular}


Table 5. PCA analysis results of anatomical and epidermal characters in Rumex species studied.

\begin{tabular}{lll}
\hline PCA & Eigenvalue & Percentage of variance \\
\hline 1 & 5.38628 & 33.664 \\
2 & 4.00992 & 25.062 \\
3 & 3.52191 & 22.012 \\
\hline
\end{tabular}

Table 6. Factor analysis results of anatomical and epidermal characters in Rumex species studied.

\begin{tabular}{|c|c|c|c|}
\hline Characters & Factor 1 & Factor 2 & Factor 3 \\
\hline Medullary vascular bundle & 0.995 & - & - \\
\hline $\begin{array}{l}\text { Presence/absence of oxalatecalcium } \\
\text { crystals }\end{array}$ & 0.995 & - & - \\
\hline Shape of sclerenchyma cap of phloem & 0.995 & - & - \\
\hline Stomata type in ventral epidermis & 0.995 & - & - \\
\hline Status of vascular bundle & - & 0.747 & - \\
\hline Average vascular bundles diameter & - & 0.710 & - \\
\hline $\begin{array}{l}\text { Average thickness of sclerenchymafi- } \\
\text { bers over phloem }\end{array}$ & - & 0.766 & - \\
\hline Average size of adaxialepidermal cells & - & 0.881 & - \\
\hline Average size of stomata & - & 0.855 & - \\
\hline Number of parenchyma layers & - & - & 0.815 \\
\hline Average size of abaxial epidermal cells & - & - & 0.765 \\
\hline
\end{tabular}

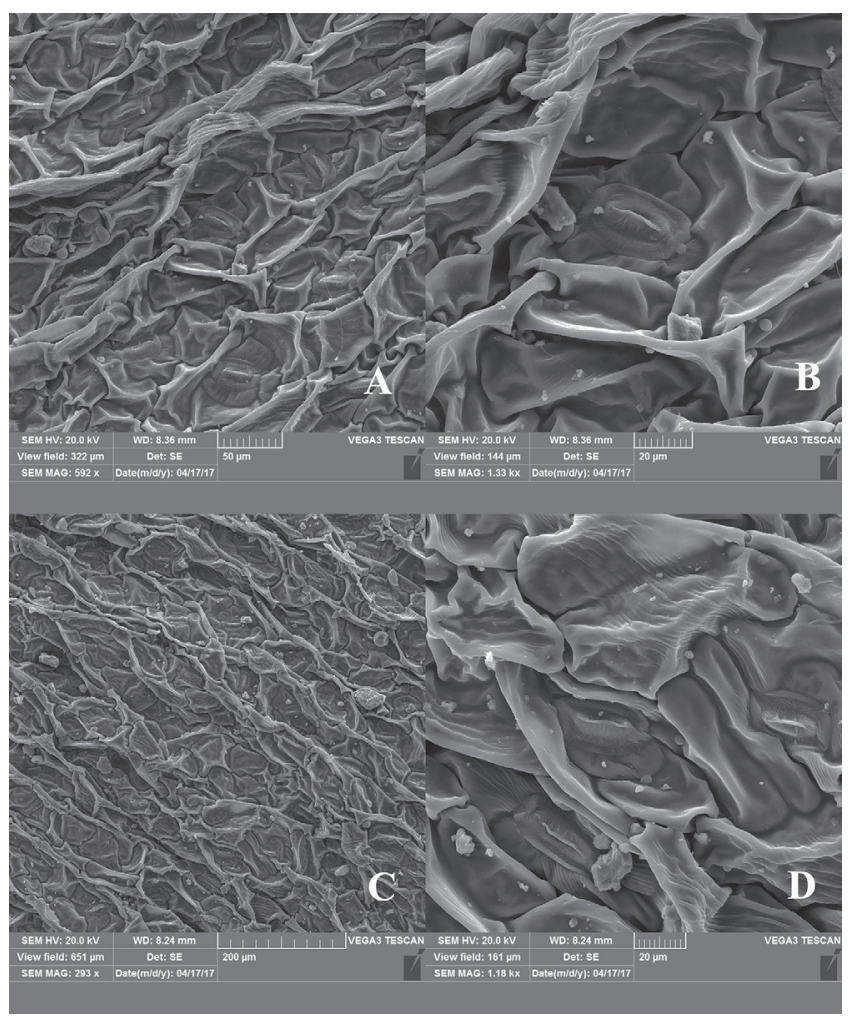

Figure 4. Leaf epidermis in R. chalepensis. A \& B) dorsal and C \& D) ventral epidermis.

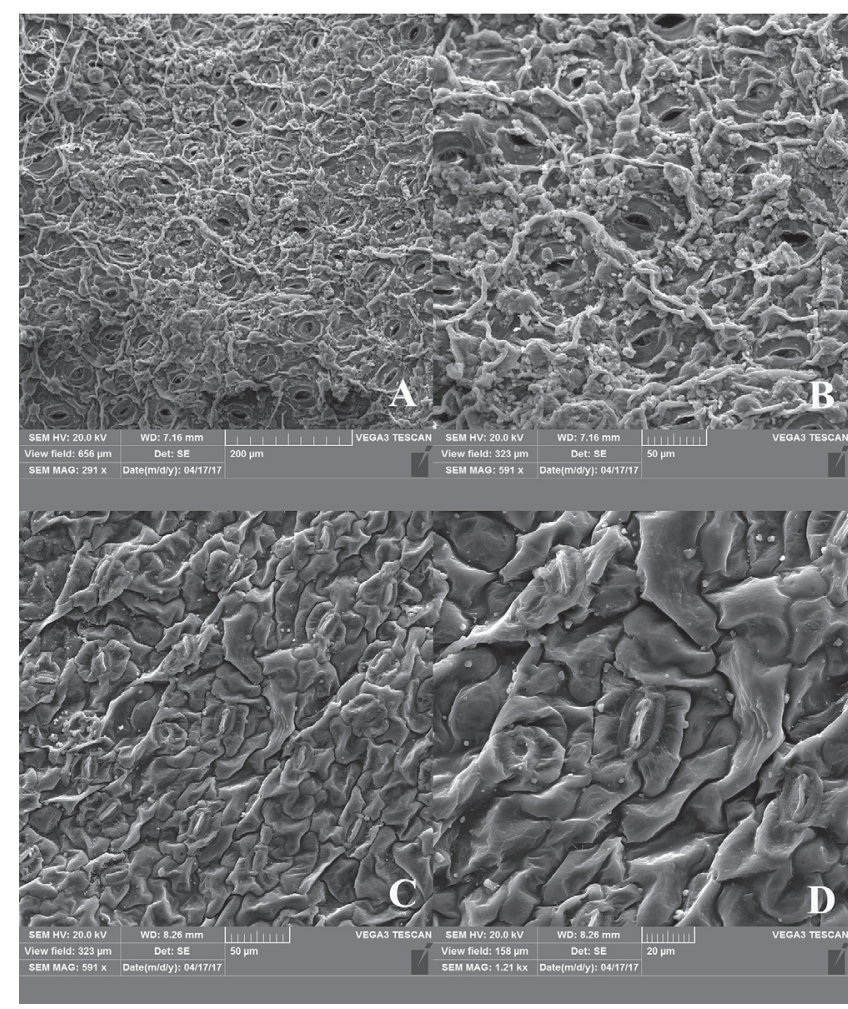

Figure 5. Leaf epidermis in $R$. conglomeratus. A \& B) dorsal and C \& D) ventral epidermis.

a mass of huge granules of wax and threads. A kind of stomata wax chimney was observed on dorsal epidermis too. Ventral epidermis is composed of wrinkled films of epicuticular wax. The stomata on dorsal epidermis are more frequent than ventral surface (Fig. 5).

Dorsal epidermis in $R$. dentatus demonstrated granules and smooth layer of epicuticular wax while ventral epidermis showed same situation with less granules (Fig. 6). In R. elbrusensis dorsal epidermis demonstrated granules and smooth layer of epicuticular wax. Ventral epidermis showed same situation with more granules (Fig. $7)$. R. pulcher showed a kind of stomata wax chimney on dorsal epidermis in addition to a mixture of granules and threads. In ventral epidermis there is no thread or granules and the stomata were less. Some kinds of platelets were observed in ventral surface (Fig. 8). In R. vesicarius dorsal and ventral epidermis is composed of wrinkled films of epicuticular wax with some kinds of crusts (Fig. 9).

\section{Statistical analyses}

ANOVA showed significant differences in quantitative characters $(\mathrm{P}<0.01)$ (Table 4). PCA analysis was done to determine the most variable characters among species studied. First three factors comprised $80.73 \%$ of total variation (Table 5). In the first PCA axis, features as 


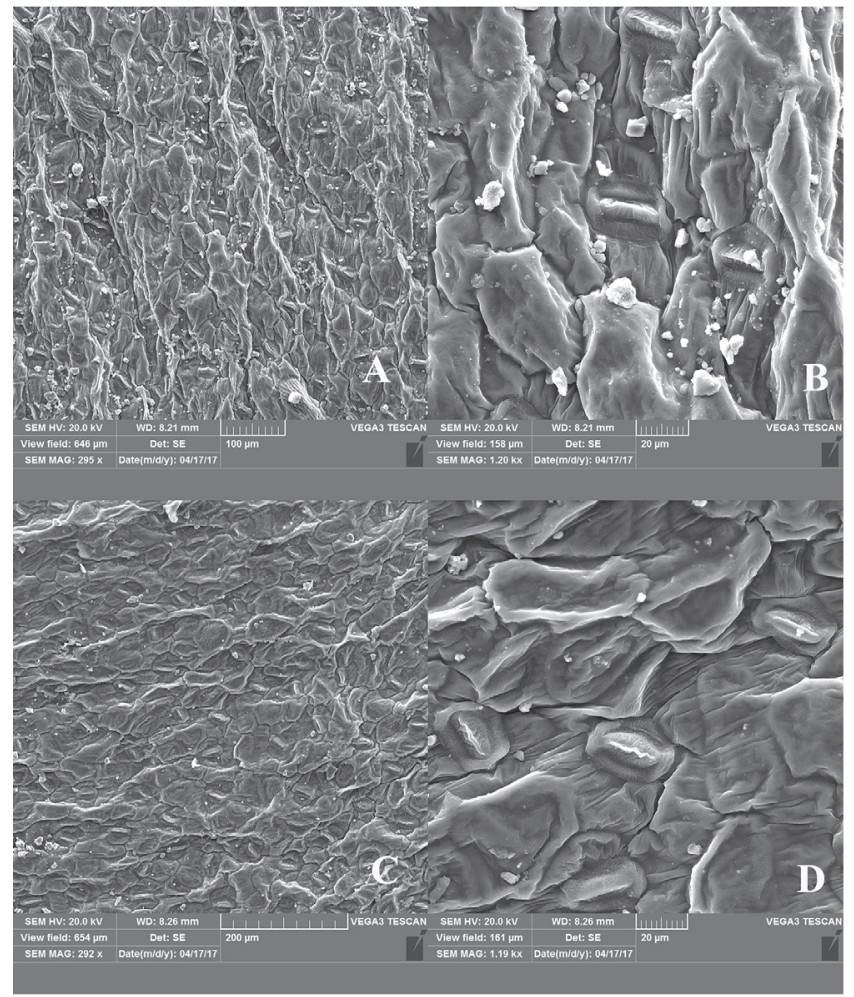

Figure 6. Leaf epidermis in $R$. dentatus. A \& B) dorsal and C \& D) ventral epidermis.

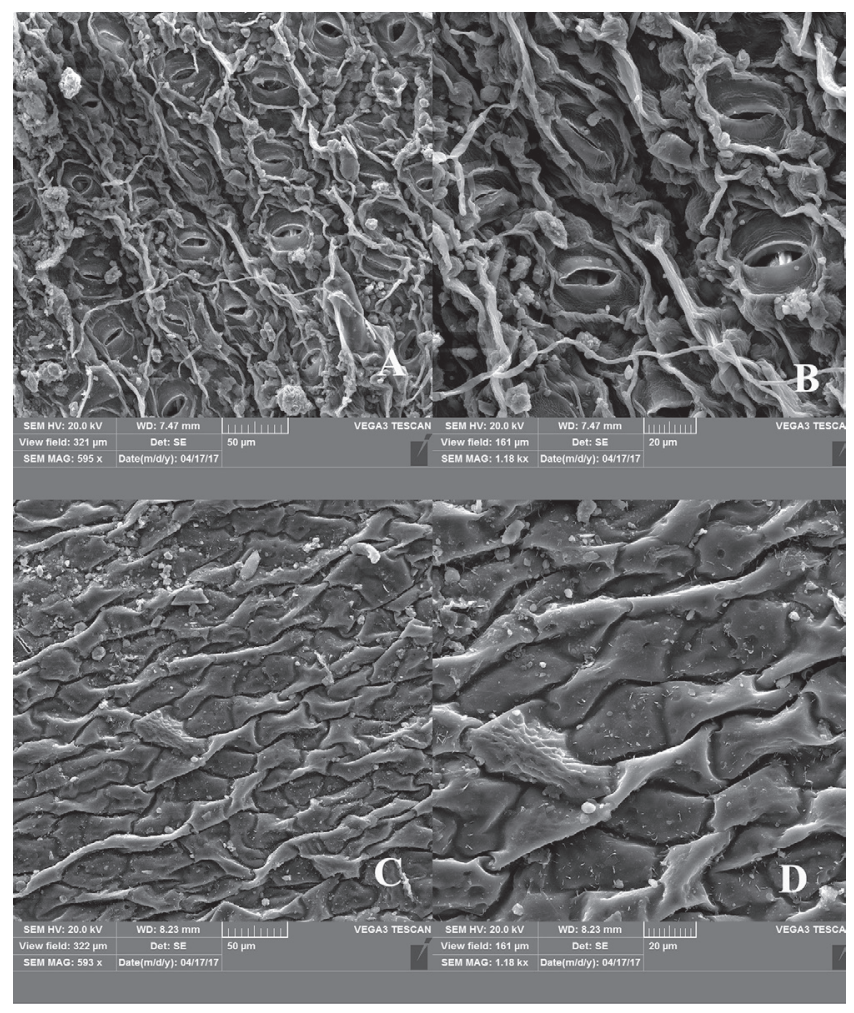

Figure 8. Leaf epidermis in R. pulcher. A \& B) dorsal and C \& D) ventral epidermis.

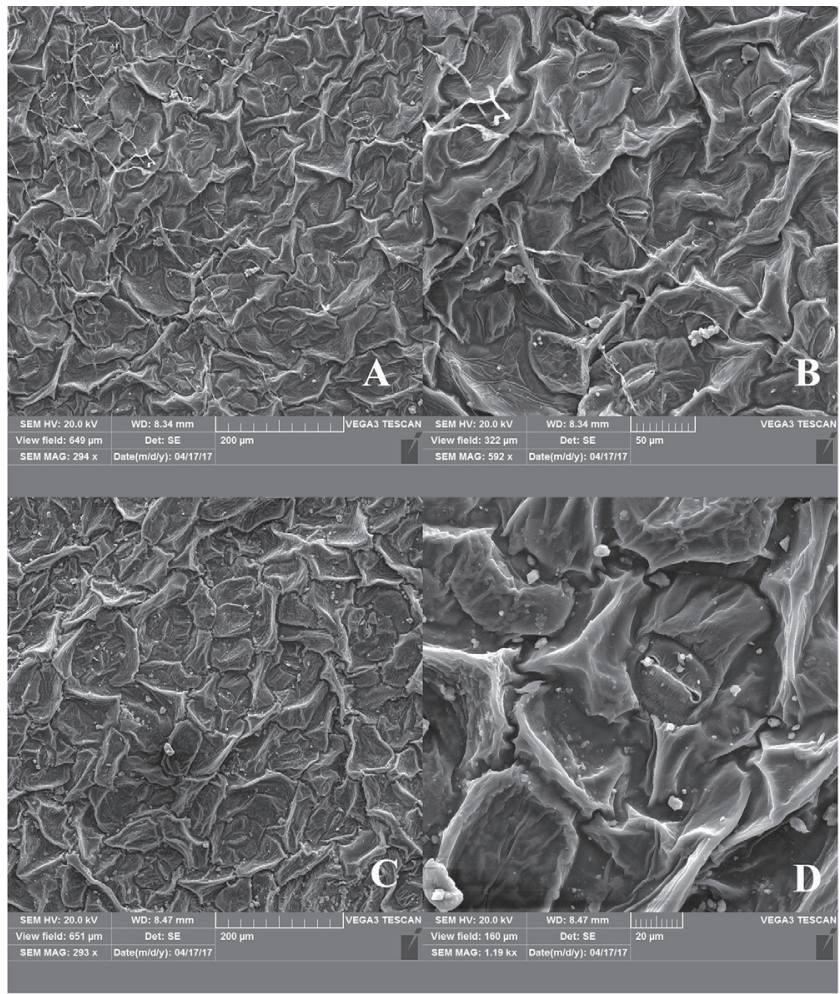

Figure 7. Leaf epidermis in R. elbrusensis. A \& B) dorsal and C \& D) ventral epidermis.

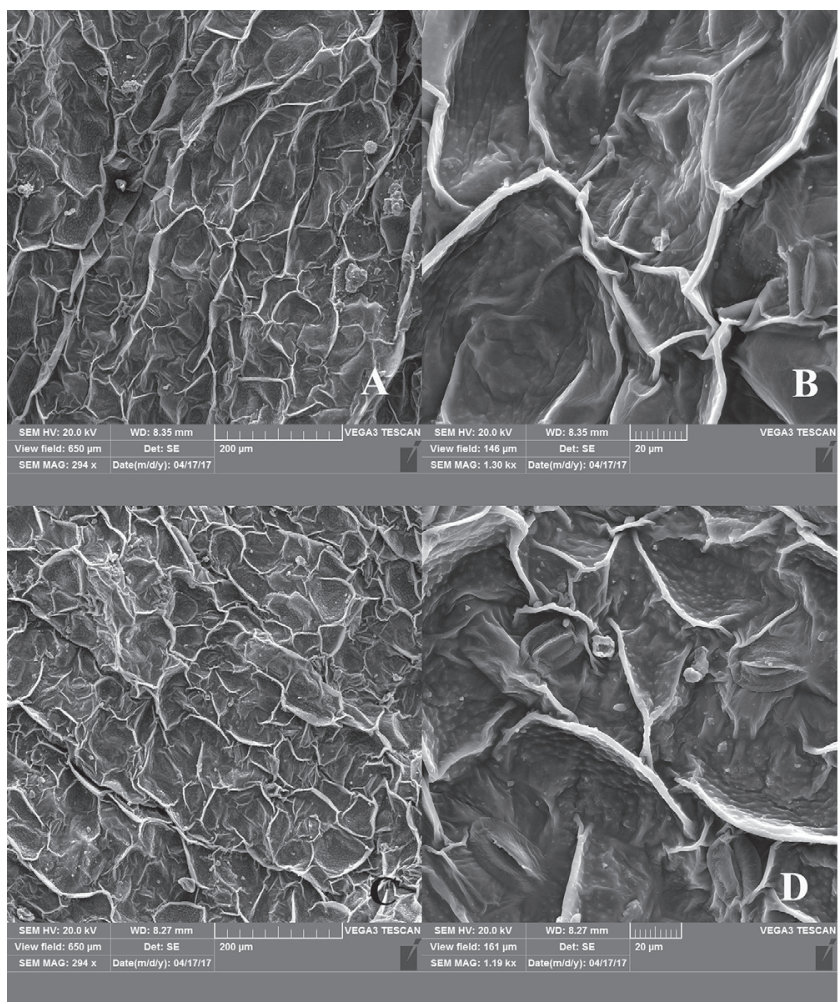

Figure 9. Leaf epidermis in $R$. vesicarius. A \& B) dorsal and C \& D) ventral epidermis. 


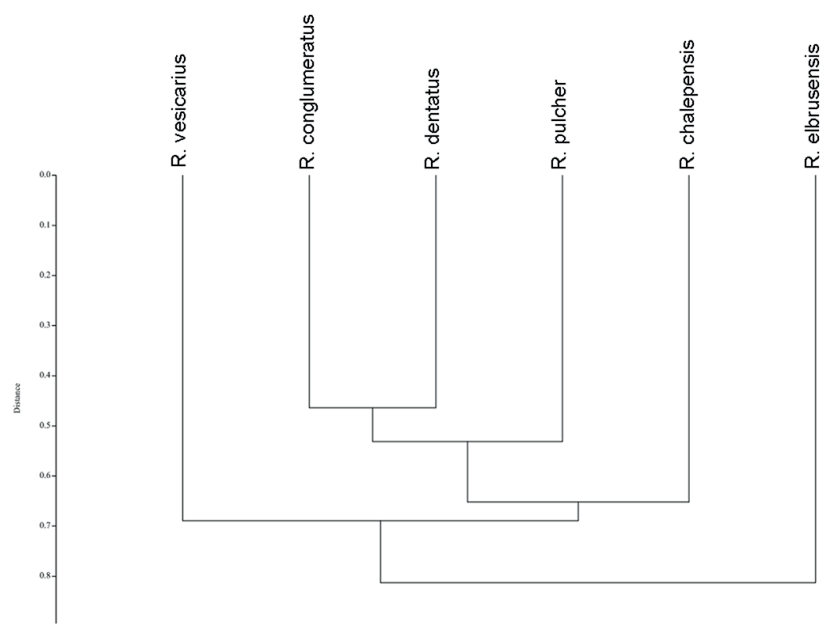

Figure 10. UPGMA tree of anatomical and micromorphological characters in Rumex species studies.

medullary vascular bundle, presence/absence of oxalate calcium crystals, shape of sclerenchyma cap of phloem and stomata type in ventral epidermis with $33.66 \%$ of total variation showed the highest correlation $(>0.7)$.

Status of vascular bundle, average vascular bundles diameter, average thickness of sclerenchyma fibers over phloem, average size of adaxial epidermal cells, average size of stomata and number of parenchyma layers and average size of abaxial epidermal cells showed the highest correlation in second and third axes, respectively (Table 6).

In UPGMA tree based on all studied characters, $R$. elbrusensis was placed in a separate sub-cluster. In the second sub-cluster, $R$. vesicarius was positioned separately while other taxa grouped together (Fig. 10). Results of PCA ordination was in agreement with UPGMA tree (Fig. 11).

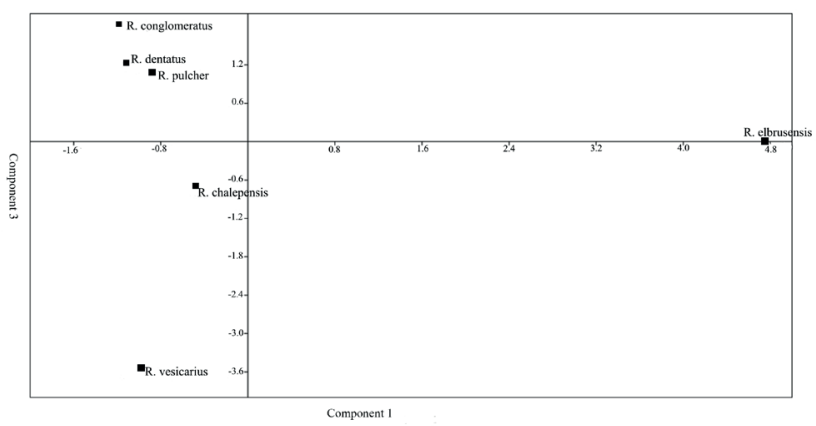

Figure 11. PCA ordination of anatomical and micromorphological characters in Rumex species studied.

\section{Discussion}

This investigation represents first detailed qualitative and quantitative study of leaf epidermis in Rumex species. It indicated the taxonomic importance of leaf epidermis in species delimitation.

Our observations showed anisocytic type of stomata in both surfaces of species studied, except R. elbrusensis with aniso-paracytic type in adaxial surface. Ahmad et al. (2009) reported amphianisocytic stomata pattern in $R$. vesicarius. Ayodele and Olwokudejo (2006) mentioned anomocytic and diacytic in other species of Rumex. Recently Yasmin et al. $(2010 \mathrm{~b})$ reported pericytic type for both leaf surfaces of $R$. chalepensis and $R$. vesicarius and peri-anisocytic type for $R$. dentatus which does not correspond to the present findings for the species studied. Considering epicuticular wax, species studied showed different patterns. In $R$. vesicarius wrinkled films can be seen in both sides, separating $R$. vesicarius from other taxa.

Previous studies on other Polygonaceae elements and different Rumex species support the usefulness of stem anatomical features in species delimitation (Hameed et al. 2010; Nazem Bokaee et al. 2015). Our studies showed the diagnostic value of these characters in studied species.

Joshi (1936) worked on the anatomy of Rumex with respect to the morphology of the internal bundles and the origin of the internal phloem. He suspected that absence of internal bundles in perennial Rumex represent the oldest forms of the genus. Among our perennial species studied (R. elbrusensis, $R$. conglomeratus, $R$. pulcher, $R$. chalepensis), only R. elbrusensis had these features therefore other perennial taxa are the oldest forms of Rumex. Our results were in agreement with other studies (Soleimani et al. 2014).

In both ordination and UPGMA tree, $R$. vesicarius was placed far from other species supporting its position in separate subgenus (Rechinger 1968; Mozaffarian 1988). Generally, our studies showed the taxonomic value of anatomical and micro-morphological characters in differentiation of this problematic genus.

\section{Acknowledgement}

The authors wish to thank Iran National Science Foundations (INSF) for the financial support of this research (grant number 95/S/45031).

\section{References}

Ahmad K, Khan MA, Ahmad M, Zafar M, Arshad M, Ahmad $\mathrm{F}$ (2009) Taxonomic diversity of stomata in dicot flora of a district tank (N.W.F.P.) in Pakistan. AJB 8(6):1052-1055.

Ayodele AE, Olowokudejo JD (2006) The family Polygonaceae in West Africa: Taxonomic significance of leaf epidermal characters. S Afr J Bot 72:442-459.

Chase M, Reveal A (2009) An update of the Angiosperm Phy- 
logeny Group classification for the orders and families of flowering plants: APG III. Bot J Linn Soc 161(2):105-121.

Hameed I, Hussain F, Dastagir G (2010) Anatomical studies of some medicinal plants of family Polygonaceae. Pak J Bot 42(5):2975-2983.

Hong SK, Ronse Decraene LP, Smets E (1998) Systematic significance of tepal surface morphology in tribes Persicarieae and Polygoneae (Polygonaceae). Bot J Linn Soc 127:91-116.

Joshi AC (1936) The anatomy of Rumex with special reference to the internal bundles and the origin of the internal phloem in the Polygonaceae. Am J Bot 23:362-369.

Keshavarzi M, Mosaferi S, Shojaii M (2012) Leaf anatomical studies of the annual species of Polygonum s.l. (Polygonaceae) in Iran. Phytol Balcan 18(2):127-133.

Lersten NR, Curtis JD (1992) Foliar anatomy of Polygonum (Polygonaceae): Survey of epidermal and selected internal structures. Plant Syst Evol 182(1-2):71-106.

Li B, Zhang WG, Chen SHF, Yang SG (2008) Comparative anatomy of the leaves of Rumex in Jiangxi J Wuhan Bot Res 26(5):443-449.

Metcalfe CR, Chalk L (1950) Anatomy of Dicotyledons, Volume 2. Clarendon Press, Oxford.

Mozaffarian V (1988) New species and new plant records from Iran. Iran J Bot 4:61-70.

Mozaffarian V (2015) Identification of Medicinal and Aromatic Plants of Iran. Farhang Moaser Press, Tehran.

Nazem BZ, Keshavarzi M, Gholami A (2015) Stem anatomical study in some annual Polygonum L. (Polygonaceae) species in Iran. Pajohes G J 28(3):647-653.

Punt WP, Hoen P, Nilsson S, Thomas L (2007) Glossary of pollen and spore terminology. Rev Paleobot Palyn 143:1-81.

Rechinger K (1968) Polygonaceae. In Rechinger K, Schlman-Czeika H (eds), Flora Iranica, Vol 56. Akademische Druck und Verlagsanstalt, Graz, 2-24.

Ronse DLP, Akeroyd JR (1988) Generic limits in Polygonum L., and related genera (Polygonaceae) on the basis of floral characters. Bot J Linn Soc 98:321-371.

Sahney M, Vibhasa (2012) Stem anatomy of medicinally importance Rumex hastatus D. Don. (Polygonaceae). Res J Agric Biol Sci 8(2):154-157.

Sanchez I, Kron KA (2008) Phylogenetics of Polygonaceae with an emphasis on the evolution of Eriogonoideae. Syst Bot 33(1):87-96.

Soleimani M, Jafari A, Nejad SKH, Amiri MD (2014) Comparative anatomical and palynological studies on Rumex L. species (Polygonaceae) in NE Iran. GJBS 4(4):111-115.

The Plant List (2013) Version 1.1. Available: http://www. theplantlist.org. Accessed 1st January.

Yasmin G, Khan MA, Shaheen N, Qaim HM (2010 a) Taxonomic significance of leaf epidermal anatomy of selected Persicaria Mill. species of family Polygonaceae from Pakistan. AJB 9(25):3759-3768.

Yasmin G, Khan MA, Shaheen N, Qaim HM (2010 b) Micro-morphological investigation of foliar anatomy of Fagopyrum Mill. And Rumex L. of Polygonaceae. Pak J Bot 42(1):47-57. 